\title{
BULLYING, CYBERBULLYING AND SOCIAL SUPPORT: A STUDY IN A PORTUGUESE SCHOOL
}

\author{
Sofia Arriaga ${ }^{1}$, Rita Garcia ${ }^{1}$, Inês Amaral ${ }^{2}$, Fernanda Daniel ${ }^{3}$ \\ ${ }^{1}$ Instituto Superior Miguel Torga (PORTUGAL) \\ ${ }^{2}$ Centro de Estudos de Comunicação e Sociedade da Universidade do Minho / Universidade \\ Autónoma de Lisboa / Instituto Superior Miguel Torga (PORTUGAL) \\ ${ }^{3}$ Instituto Superior Miguel Torga / CEIS-UC - Centro de Estudos e Investigação em Saúde \\ da Universidade de Coimbra / CIES - Centro de Investigação e Estudos de Sociologia - \\ ISCTE-IUL (PORTUGAL)
}

\begin{abstract}
This paper presents a study that was developed with a sample of middle and high school students of the 3rd cycle of a Portuguese school, with an average age of 13.52 years $(S D=0,96)$ and an almost equal distribution in terms of sex (73 males vs. 70 females) and schooling (44 in the 7th year, 49 in the 8th year and 50 in the 9th year). The results show a prevalence of Observation Behaviour in the Victimization Scale and School Aggression and the dimension Satisfaction with Family in Satisfaction Scale Social Support. It was found that $37 \%$ of the sample has experienced Cyberbullying and $59 \%$ have had knowledge of Cyberbullying situations, which correlates positively with the Observation and Victimization behaviours of Victimization Scale and School Aggression.
\end{abstract}

Keywords: Bullying; Cyberbullying; Social Support; Victimization; Aggression.

\section{INTRODUCTION}

Violence is an important and growing public health problem, which has serious individual and social consequences particularly for children and young people [1]. In recent years violence has been gaining prominence news, bringing up the concerns of parents and educators. In fact, a serious problem that is present in today's society is violence in schools [2]. This phenomenon can be understood as something more extensive that refers us to diverse domains, such as antisocial behaviour, delinquency and vandalism, among others ([3], [4]). ICT have broadened the phenomenon of bullying to Cyberbullying ([5], [6]).

Bullying behaviours are presented as aggressive acts that have the purpose of causing distress or harm. These behaviours present an imbalance of power and strength between the aggressor and the victim, occurring several times over time ([7], [8], [9]) regardless of socioeconomic status, gender or age group ([10], [11], [12]). According to Olweus [13], bullying is a behaviour that poisons the school environment and conditions learning, given that many children and adolescents, victims of this phenomenon, develop fears, phobias, panic and psychosomatic problems.

Martins [14] argues that there are three forms of bullying according to the behaviours evidenced. In the first form, direct and physical behaviours involving various acts such as physical assault, theft of foreign objects, extortion of money and coercion on an individual are assumed, forcing them to engage in sexual behaviour. The second form of bullying involves direct and verbal behaviours such as racist, homophobic or otherwise demonstrative insults, epithets, actions, and comments. Finally, there are indirect behaviours that are based on the systematic exclusion of people to achieve some favour, which is reflected in rumours, threats or manipulation of the social life of others. This gives rise to three protagonists of bullying behaviours: aggressors, victims and witnesses.

The aggressors are characterized by not demonstrating self-control [15] and more likely to express a high level of inattention and hyperactivity in school [16]. Aggressors also tend to exert power through physique force to frighten their victims and use their leadership skills and attitudes to dominate other children or young people [17]. Several studies point out that aggressors are poorly supervised by parents and live in environments where the model of problem solving is aggressive or impulsive behaviour [18].

The other protagonists are bullying victims, who Jabes and Costa [2] have characterized in three types: passive, the provocative and the aggressor. Passive victims are usually very shy, demonstrate difficulty of socialization, and do not oblige either verbal or physical, showing a fragile structure. The 
provocative victims are children and adolescents who like to provoke, attract attention, and usually argue when they are beaten or insulted. The aggressors victims are characterized by not reacting when they are assaulted, but later transfer this anger to others that are weak and defenceless, using aggression as a way to manage the most negative feelings.

Another protagonist of bullying behaviour is the public or witness, as stated by Trevisol and Uberti [19]. Usually, witnesses cannot help victims by inability to know what to do, for fear of becoming victims or worsen the situation [20].

The behaviour of young people has been changed with the use (and social use) of Information and Communication Technologies (ICT). ICTs have allowed the creative and autonomous use of a set of new media that prove to be beneficial, but also bring obvious risks and dangers [21]. In this sense, the development of ICT has contributed to the transfer of bullying to the virtual world. This phenomenon is associated with intentional psychological violence, which involves negative behaviours such as lies, threats, insults, defamation, intimidation, rumours, provocation and social exclusion, among other attitudes [22].

Cyberbullying is a type of violence that is practiced through the sending of emails, text messages, the dissemination of offensive photos and videos on social media, manipulation of images, insults in chat rooms or social networks. All of these assaults can be anonymous and cover a huge audience in the shortest possible time ([23] [24). In the context of cyberspace the audience is exponentially increased and the content can become viral. In digital media, anonymity also encourages a more aggressive and harmful attitudes by the offenders.

Pinheiro [25] argues that the behaviour of the aggressors in Cyberbullying can be divided into two types. The first concerns accidental attackers. The second typology is the adventurer aggressors who practice this act a first time and, taking advantage, this same behaviour becomes an addiction. Cyberbullying adventurers spend a lot of time on the personal pages of their victims, creating situations that can lead to total despair.

The consequences of Cyberbullying are as profound and devastating as those of bullying, if not more, because they evidence a larger audience and, consequently, a humiliation on a substantially higher scale than the school environment. In this sense, the consequences can translate into risk of suicide and self-mutilation [5]. According to Childnet International and the Multidisciplinary Center for Studies and Guidance on School Bullying [6], socialization losses and low self-esteem are the most common victims of Cyberbullying, which tend to isolate themselves as a way to protect themselves. The physical and emotional health of the victim also manifests itself in many aspects such as anxiety, sadness, stress, fear, apathy, anguish, repressed rage, headaches, sleep disorders, loss of appetite, isolation. Many of these consequences continue throughout the life of the victim, even after the attacks have been completed.

Lima [26] argues that social support is composed of several protective and adequate factors that the environment is able to promote in individuals, giving them tools for them to cope with stressful events. The way people assess their social support is apparently more important than their own interpersonal relationships [27]. This question can be explained by the importance of the meanings that people attribute to what happens to them.

Several authors divide social support into two parts - social support received and perceived social support. The social support received is what individuals actually receive from someone else. Perceived social support is what is available if the individual needs, always depending on the availability of others [28]. The support and social support provided by other causes feelings of well being and allows to perceive the affection and respect that people have for the subject. Thus, family and friends play an important role because they are the most important source of social support.

The various types of social support may come from the family, close friends, neighbours, co-workers or the school and the community itself [29]. It follows that the various roles of the interactions that the subject carries out throughout life are translated into the constructions of a social network, which may or may not help in the participation, exploration and experience of some situations.

Social support over time has been related to the personality and adaptation of the individual, but also to health, thus creating one of the areas of great growth in research and application in Psychology [27]. It has been scientifically demonstrated that social support is a very important factor in protecting the individual and his life, being crucial in the health and well being of the individual [30]. 
The phase of adolescence is marked by the diversification of the social support of the individual [31], constituting a stage where the influence of the group of friends grows and the support that is given by the parents is seen as less necessary. Thus, less cohesive relationships with caregivers are sometimes developed [32]. The network of friendships is seen as a source of social support and is related to high levels of psychosocial well being, as well as reduced levels of aggressiveness towards friends. However, this social support is not always stable over time [33]. In early adolescence, sometimes young people find there is more conflict but feel more protected and supported by their peer group, compared with young people who are at the end of their adolescence [34].

\section{METHOD}

The study was designed to analyse bullying and Cyberbullying in a school context and its links with support and social support of adolescents. The case study was developed with 145 students of the 3rd cycle of a school with a contract of association with the Portuguese State and belonging to a religious community. The main objective was to assess the perceptions that young people have of bullying and Cyberbullying in order to establish correlations and direct links with social support. In this study, we sought to understand whether young people who feel more satisfied with the support they receive from others are less subject to bullying and/or Cyberbullying (as victims or as aggressors) and if there is any relation to social isolation. To analyse the relation between bullying, Cyberbullying and social support, the following measuring instruments were used: socio-demographic questionnaire, Scale of Victimization and School Aggression, Cyberbullying questionnaire, Social Support Satisfaction Scale and Questionnaire on Internet use.

\subsection{Participants}

145 adolescents with 7 to 12 years of schooling composed our sample, with the majority attending the 8th year of schooling $(n=51,35.2 \%)$. The majority of students were male $(n=73,50.3 \%)$. The age of adolescents is between 12 and 16 years of age, with an average age of 13.52 years.

114 of the respondents reported having no siblings, with a correspondence of $78.6 \%$ in a total of 145 students. 101 of the 145 respondents have parents who are married or living together, which represents a percentage of 69.7. Only three respondents did not answer this question. We found that 110 respondents answered that their household is a nuclear family $(75.9 \%) .21 .4 \%$, of the students reported that their family is nuclear and extended. Only two reported having a large family.

According to the data collected, 112 adolescents never failed in their studies $(77.2 \%)$ and 33 of the respondents had already failed, with a correspondence of $22.8 \%$ in the total sample. 74 respondents do not have extracurricular activities, corresponding to a percentage of $51 \%$. It should also be noted that 71 of the respondents answered that they have extracurricular activities (49\%). Regarding the way students study, we found that the majority of respondents studied alone, with a correspondence of 103 young people in 145 of the respondents $(71 \%)$. It should be noted that one respondent did not answer this question.

\subsection{Instruments}

The Scale of Victimization and School Aggression (SVSA) analyses the behaviours mentioned by the individual in situations of aggression, victimization and observation in a school context [46]. This is a pioneer scale in Portugal to explore the type and degree of involvement of a subject in bullying situations. The SVSA consists of 70 items measured on a four-point scale, related to the frequency of behaviours. Higher results indicate frequencies of higher behaviours ([35]; [36]). The items in the scale are grouped into three specific factors: aggression behaviour (factor 1); observation behaviour (factor 2 ); victimization behaviour (factor 3 ). Regarding the psychometric qualities, this instrument presents good internal consistency levels for each factor, with Cronbach's alpha values between 0.914 and 0.962 (factor 1: 0914; factor 2: 0.962 and factor 3: 0934) ([35]; [36]).

The Cyberbullying Questionnaire (CBQ) [37]; Portuguese version of [38] is a self-response instrument with the purpose of evaluating the frequency of types of behaviours related to cyberbullying. Participants are asked to indicate how often they performed the behaviour described in each item, according to a 3-point scale [38]. In the original questionnaire the psychometric qualities of the CBQ showed to be adequate. The study of its reliability showed a high internal consistency (Cronbach's alpha equal to 0.96) [48]. In the Portuguese sample of $C B Q$, from the study of Pinto and Cunha [49], the questionnaire also revealed good internal consistency (Cronbach's alpha equal to 0.9 ). 
The Cyberbullying Questionnaire - Victimization (CBQ-V) ([48]; Portuguese version: translation and adaptation of [49]) is an instrument of self-response that aims to complement the previously mentioned questionnaire by assessing the frequency of different forms of victimization caused by cyberbullying [50]. Participants are asked to note the frequency with which they were victims of the behaviour described in each item, on a 3-point scale [51]. In the original questionnaire, the CBQ-V presented good internal consistency, revealing a Cronbach's alpha of 0.95 [51]. In the Portuguese sample, the $C B Q-V$ revealed a Cronbach's alpha of 0.77 , which still indicates adequate internal consistency [51].

The Social Support Satisfaction Scale (SSSS) was developed and validated by Ribeiro [30] and is an instrument that evaluates the degree of satisfaction with social support. It consists of a self-completion scale composed by four dimensions: 1 = satisfaction with friends, which measures satisfaction with friendships; 2 = intimacy, which measures the perception of the existence of intimate social support; 3 = family satisfaction, which measures satisfaction with existing family social support; 4 = social activity, which measures the satisfaction with the social activities that the subject performs. The SSSS has an internal consistency of 0.85 , the dimension satisfaction with friends is 0.83 , the dimension intimacy and family satisfaction is 0.74 , and finally the dimension social activity is of 0.64 [52].

The questionnaire on Internet use is a tool that was built from scratch to help assess how adolescents use the new technologies and the Internet, and to gauge whether overuse can harm their lives. This questionnaire is based on another one already existing: "Digital Rights: a password for the future" [39] Our questionnaire consists of 17 questions, the majority of which is directed to the use of the Internet. The remaining issues are oriented to the situation of Internet violence, i.e. cyberbullying.

\subsection{Statistical analysis}

Statistical analyzes were performed using the software Statistical Package for the Social Sciences (SPSS), version 21. In the descriptive analysis of the variables we used measures of central tendency and dispersion; the $t$-Test and analysis of variance (ANOVA) were used in the detection of differences. For the analysis of the psychometric properties, internal consistency was determined by Cronbach's alpha.

\section{RESULTS}

The questionnaire on Internet use showed that more than half of respondents use the network every day $(n=119 ; 82.1 \%)$, thus occupying an average time of 3 hours per day browsing the Internet $(n=$ 46; $31.7 \%)$. The computer / laptop (80\%) is the most widely used device for accessing the Internet, followed by the mobile phone $(70.3 \%)$, tablet $(32.4 \%)$, television $(11 \%)$ and school computer $(4.8 \%)$. Regarding the question "Do you establish new relationships with other people on the Internet?" 55 of the subjects answered "rarely" (37.9\%). Respondents were also asked regarding the number of profiles they have on social networks and $83(57.2 \%)$ responded that they only have one profile.

Regarding online risk issues, namely "Did you report what happened?", "Do you know the people involved?", "Have you asked for help?" and "Has the situation been resolved?", $65.5 \%$ of respondents answered that they did not report the situation; $74.5 \%$ of respondents do not know the people involved; $60.7 \%$ of the sample never asked for help regarding the situations experienced; and $49 \%$ of students say that the situation was finally resolved. To the question "Do you know if a friend has lived a situation like these" 60 of respondents had never been aware of any situation; 30 of the respondents were aware of one situation, 17 of the subjects reported 2 cases; 23 of the respondents had knowledge of three situations; 9 students were aware of 4 cases; 4 of the respondents were aware of 5 situations and, finally, two of the respondents were aware of all of the situations. To the question "Have you ever experienced any of these situations?", and compared to previous results, 91 of the respondents never lived in any situation; 40 of the subjects have experienced one situation; 8 of respondents have experienced these two situations and finally 6 of the respondents lived 3 of these 6 cases.135 subjects (93.1\%) answered yes to the question "Are you informed about the use of the dangers of the Internet?".

The results demonstrate that Behaviour of Observation (participation as a witness) is the most frequent type of behaviour among individuals involved in Bullying situations $(M=1.62, S D=0.42)$. The prevalence of Victimization Behaviour $(M=1.36, S D=0.35)$ on Aggression Behaviour $(M=1.10$, $S D=0.35$ ) was also observed as showed in tab. 1 . It is also verified that in the Satisfaction with Social Support Scale, the dimension that shows a higher punctuation media is Family Satisfaction $(M=3.86$, 
$D P=1.19)$, followed by the dimension Social Activity dimension $(M=3.03, S D=1.04)$, the Family Satisfaction with Friends dimension $(M=2.32, S D=0.63)$. The Intimacy $(M=2.21, S D=0.53)$ is the last one to be listed.

Table 1. Descriptive analysis of the dimensions of the School Victimization and Aggression Scale and the Social Support Satisfaction Scale

\begin{tabular}{|c|c|c|c|c|c|c|c|c|c|}
\hline \multicolumn{5}{|c|}{ Scale of Victimization and School Aggression } & \multicolumn{5}{|c|}{ Social Support Satisfaction Scale } \\
\hline & Min. & Max. & $M$ & $S D$ & & Min. & Max. & $M$ & $S D$ \\
\hline AB & 1 & 1.81 & 1.10 & 0.15 & SF & 1 & 3.13 & 2.32 & 0.63 \\
\hline OB & 1 & 3.25 & 1.62 & 0.42 & IN & 1 & 3.33 & 2.21 & 0.53 \\
\hline \multirow[t]{2}{*}{ VB } & 1 & 2.53 & 1.36 & 0.35 & SA & 1 & 5.00 & 3.03 & 1.04 \\
\hline & & & & & FS & 3 & 15 & 11.59 & 3.57 \\
\hline
\end{tabular}

$A B=$ aggression behaviour; $O B=$ observation behaviour; $V B=$ victimization behaviour; Min = minimum; $S F=$ satisfaction with friends; IN = intimacy; $S A$ = social activity; $F S=$ family satisfaction; $M a x=$ maximum; $M=$ mean; $\mathrm{SD}=$ standard deviation.

Statistically significant differences were not confirmed in the Victimization and School Aggression Scale nor in the Cyberbullying Questionnaire and the Victimization Cyberbullying Questionnaire according to gender, age and schooling as shown in tab. 2 and 3.

Table 2. Differences in Scale of Victimization and School Aggression according to Sex, Age and Schooling

\begin{tabular}{|c|c|c|c|c|c|c|c|c|c|}
\hline & \multicolumn{3}{|c|}{$A B$} & \multicolumn{2}{|c|}{ OB } & \multicolumn{4}{|c|}{ VB } \\
\hline & $M$ & $S D$ & $t / \mathrm{F}^{p}$ & $M$ & $S D$ & $t / F^{p}$ & $M$ & $S D$ & $t / \mathrm{F}^{p}$ \\
\hline Male & 34.25 & 4.19 & $0.34^{\mathrm{ns}}$ & 38.14 & 10.05 & $0.91^{\mathrm{ns}}$ & 19.67 & 4.92 & $1.65^{\mathrm{ns}}$ \\
\hline Fem. & 33.99 & 4.97 & & 39.70 & 9.95 & & 21.13 & 5.51 & \\
\hline 12 years & 33.15 & 4.91 & $0.75^{\mathrm{ns}}$ & 39.55 & 12.24 & $1.19^{\mathrm{ns}}$ & 20.00 & 6.64 & $1.56^{\mathrm{ns}}$ \\
\hline 13 years & 33.83 & 4.74 & & 40.88 & 10.08 & & 21.42 & 5.41 & \\
\hline 14 years & 34.08 & 3.50 & & 38.86 & 8.82 & & 20.00 & 4.78 & \\
\hline 15 years & 36.70 & 7.84 & & 34.75 & 8.42 & & 19.09 & 5.04 & \\
\hline 16 years & 35.60 & 5.41 & & 32.00 & 9.99 & & 21.25 & 3.86 & \\
\hline $7^{\text {th }}$ grade & 33.81 & 4.40 & $0,17^{\mathrm{ns}}$ & 40.55 & 10.51 & $0.77^{\mathrm{ns}}$ & 20.63 & 5.35 & $0.10^{\mathrm{ns}}$ \\
\hline $8^{\text {th }}$ grade & 34.38 & 4.84 & & 38.13 & 9.90 & & 20,47 & 5.34 & \\
\hline $9^{\text {th }}$ grade & 34.13 & 4.56 & & 38.35 & 9.67 & & 20,14 & 5.21 & \\
\hline
\end{tabular}

n.s. non-significant; $M=$ mean; $S D=$ standard deviation; $F$ = ANOVA, $p=$ level of statistical significance; $A B=$ aggression behaviour; $\mathrm{OB}=$ observation behaviour; $\mathrm{VB}=$ victimization behaviour; SVSA = Scale of Victimization and School Aggression 
Table 3. Differences from the Cyberbullying Questionnaire and the Victimization Cyberbullying Questionnaire according to Sex, Age and Schooling

\begin{tabular}{|c|c|c|c|c|c|c|}
\hline & \multicolumn{3}{|c|}{ CBQ } & \multicolumn{3}{|c|}{ CBQ-V } \\
\hline & $M$ & $S D$ & $t / F^{p}$ & $M$ & $S D$ & $t / \mathrm{F}^{p}$ \\
\hline Male & 1.28 & 1.59 & $0.51^{\mathrm{ns}}$ & 0.70 & 1.21 & $1.43^{\mathrm{ns}}$ \\
\hline Fem. & 1.15 & 1.44 & & 1.04 & 1.56 & \\
\hline 12 years & 0.90 & 1.60 & $0.42^{\mathrm{ns}}$ & 0.66 & 0.91 & $1.01^{\mathrm{ns}}$ \\
\hline 13 years & 1.34 & 1.50 & & 1.18 & 1.68 & \\
\hline 14 years & 1.20 & 1.51 & & 0.82 & 1.40 & \\
\hline 15 years & 1.27 & 1.27 & & 0.66 & 1.15 & \\
\hline 16 years & 1.75 & 2.21 & & 0.20 & 0.44 & \\
\hline $7^{\text {th }}$ grade & 1.02 & 1.40 & $0.81^{\mathrm{ns}}$ & 0.84 & 1.21 & $2.49^{\text {ns }}$ \\
\hline $8^{\text {th }}$ grade & 1.20 & 1.36 & & 0.58 & 1.27 & \\
\hline $9^{\text {th }}$ grade & 1.42 & 1.73 & & 1.20 & 1.62 & \\
\hline
\end{tabular}

n.s. non-significant; $M=$ mean; $S D=$ standard deviation; $t=t$-test, $F=A N O V A, p=$ level of statistical significance; $\mathrm{CBQ}=$ Cyberbullying Questionnaire; $\mathrm{CBQ}-\mathrm{V}=$ Victimization Cyberbullying Questionnaire

There were statistically significant differences in the Satisfaction with Social Support Scale, more specifically in the Family Satisfaction dimension $(t=2.05, p<0.05)$, in the Intimacy dimension $(t=2.61$, $p<0.01)$ and in Social Activity $(t=2.86, p<0.01)$, according to sex, age and schooling as it appears on tab. 4.

Table 4. Differences from the Satisfaction with Social Support Scale according to Sex, Age and Schooling

\begin{tabular}{|c|c|c|c|c|c|c|c|c|c|c|c|c|}
\hline & \multicolumn{3}{|c|}{ SF } & \multicolumn{3}{|c|}{ IN } & \multicolumn{3}{|c|}{ SA } & \multicolumn{3}{|c|}{ FS } \\
\hline & $M$ & $S D$ & $t / \mathrm{F}^{p}$ & $M$ & $S D$ & $t / \mathrm{F}^{p}$ & $M$ & $S D$ & $t / \mathrm{F}^{p}$ & $M$ & $S D$ & $t / \mathrm{F}^{p}$ \\
\hline Male & 19.71 & 4.77 & $1.48^{\mathrm{ns}}$ & 13.93 & 2.90 & $2.61^{* *}$ & 9.79 & 2.92 & $2.86^{\star *}$ & 12.19 & 3.03 & $2.05^{\star}$ \\
\hline Fem. & 17.92 & 5.27 & & 12.56 & 3.34 & & 8.35 & 3.16 & & 10.99 & 3.97 & \\
\hline 12 years & 17.43 & 5.33 & $0.89^{\mathrm{ns}}$ & 13.33 & 3.91 & $1.48^{\mathrm{ns}}$ & 8.76 & 2.18 & $1.35^{\mathrm{ns}}$ & 10.90 & 3.52 & $0.64^{\mathrm{ns}}$ \\
\hline 13 years & 18.93 & 4.19 & & 12.32 & 3.05 & & 8.91 & 3.25 & & 12.00 & 2.97 & \\
\hline 14 years & 18.59 & 5.61 & & 13.73 & 3.06 & & 9.03 & 3.01 & & 11.48 & 4.11 & \\
\hline 15 years & 20.09 & 2.94 & & 13.83 & 3.04 & & 9.17 & 3.81 & & 12.42 & 2.15 & \\
\hline 16 years & 16.00 & 6.63 & & 14.00 & 2.12 & & 12.20 & 4.38 & & 10.40 & 4.27 & \\
\hline $7^{\text {th }}$ grade & 18.20 & 5.14 & $0.37^{\mathrm{ns}}$ & 12.95 & 3.34 & $1.00^{\mathrm{ns}}$ & 8.52 & 2.49 & $1.03^{\mathrm{ns}}$ & 11.57 & 3.46 & $0.45^{\mathrm{ns}}$ \\
\hline $8^{\text {th }}$ grade & 18.28 & 5.10 & & 13.00 & 3.15 & & 9.24 & 3.59 & & 11.26 & 3.73 & \\
\hline $9^{\text {th }}$ grade & 19.04 & 4.99 & & 13.78 & 3.09 & & 9.40 & 3.10 & & 11.94 & 3.55 & \\
\hline
\end{tabular}

${ }^{*} p<.05 ;{ }^{* *} p<.01 ;$ n.s. non-significant; SF = satisfaction with friends; IN = intimacy; SA = social activity; FS = family satisfaction; $\mathrm{M}=$ mean; $\mathrm{SD}=$ standard deviation; $\mathrm{t}=\mathrm{t}$-test; $\mathrm{F}=$ ANOVA, $\mathrm{p}=$ level of statistical significance

It can be seen in tab. 5 that the 3 dimensions of the Scale of Victimization and School Aggression correlate positively and significantly between them $(r=.43, n=145, p<.01-\mathrm{AB}$ vs. OB; $r=.35, n=$ $145, .01-\mathrm{AB}$ vs. VB; $r=.51, n=145, p<.01$ - OB vs. VB).

We observed the correlations of these dimensions with the other variables and found that the dimension "aggression behaviour" presents a small positive significant correlation with the variable 
"number of known situations that can configure or enhance Cyberbullying" $(r=.17, n=145, P<.05$ $A B$ vs. IQ-10). In the "observation behaviour" dimension, in addition to the correlation detected with "number of known situations that can configure or enhance Cyberbullying" $(r=.36, n=145, p<.01$ $\mathrm{OB}$ vs. IQ-10). The correlation was also positive, mean and significant with the variable "number of situations experienced that can configure or enhance Cyberbullying" ( $r=.35, n=145, p<.01-\mathrm{OB}$ vs. IQ-11)

In the dimension "victimization behaviour" in addition to find association with the variables "number of known situations that can configure or enhance Cyberbullying" and "amount of experienced situations that can configure or enhance Cyberbullying" ( $r=.32, n=145, p<.01-$ VB vs. IQ-10; $=.33, n=145$, $p<.01-$ VB vs. IQ-11, respectively), we found negative and significant correlations with all dimensions of the Social Support Satisfaction Scale $(r=-.30, n=145, p<.05-$ VB vs. SF; $r=-.41, n$ $=145, p<.01-$ VB vs. IN; $r=-.24, n=145, p<.01-$ VB vs. SA; $r=-.26, n=145, p<.01-$ VB vs. FS). Regarding the Cyberbullying questionnaire, a mean positive and significant relation was found with the questionnaire complemented by Cyberbullying-Victimization $(r=.41, n=145, p<.05-C B Q$ vs. $C B Q-V)$. In the $C B Q$ questionnaire, a statistically significant association with the "satisfaction with friends" dimension ( $r=.20, n=145, p<.05-\mathrm{CBQ}$ vs. SF) was found. In the CyberbullyingVictimization questionnaire, a statistically significant association was found with the variable "number of situations experienced that could configure or enhance Cyberbullying" $(r=.20, n=145, p<.01$ $\mathrm{CBQ}-\mathrm{V}$ vs. IQ-11).

As for the scale of "Satisfaction with Social Support" we note that not all scale dimensions have statistically significant associations. The "Satisfaction with Friends" dimension shows strong positive associations with "Intimacy" ( $r=.58, n=145, p<.01$ - SF vs. IN) and "Satisfaction with the Family" $(r=$ .67, $N=145, p<.01$ - SF vs. SA). The "intimacy" dimension shows small and medium positive associations with "Family Satisfaction" $(r=.35, n=145, p<.01$ - IN vs. SA) and with "Social Activity" ( $r$ $=.27, n=145, p<.01-$ In vs. FS). The dimension "Satisfaction with Family" shows a strong positive association with the "Social Activity" ( $r=.88, n=145, p<.01$ - SA vs. FS). The two questions about the "number of known situations that can configure or enhance Cyberbullying" and the "number of situations experienced that can configure or enhance Cyberbullying" have a positive association ( $r=$ .30, $n=145, p<.01-I Q-10$ vs. IQ-11).

Table 5. Pearson's Correlations between the Scale of Victimization and School Aggression and its dimensions, Cyberbullying Questionnaire and Victimization Cyberbullying Questionnaire, Questions of Questionnaire on Internet use and Dimensions of the Satisfaction Scale with Social Support

\begin{tabular}{|c|c|c|c|c|c|c|c|c|c|c|c|c|}
\hline \multicolumn{13}{|c|}{ Correlations } \\
\hline Instruments & 1 & 2 & 3 & 4 & 5 & 6 & 7 & 8 & 9 & 10 & 11 & 12 \\
\hline 1-BA & - & $0,43^{\star *}$ & $0,35^{\star *}$ & $0,66^{\star *}$ & 0,12 & 0,12 & $-0,06$ & 0,01 & 0,06 & 0,04 & $0,17^{\star}$ & 0,15 \\
\hline 2-OB & & - & $0,51^{* *}$ & $0,92^{\star *}$ & 0,04 & 0,09 & $-0,09$ & $-0,09$ & $-0,06$ & $-0,21$ & $0,36^{* *}$ & $0,35^{\star *}$ \\
\hline 3-VB & & & - & $0,75^{\star *}$ & 0,04 & $0,18^{*}$ & $-0,30^{*}$ & $-0,41^{* *}$ & $-0,24^{* *}$ & $-0,26^{* *}$ & $0,32^{* *}$ & $0,33^{*}$ \\
\hline 4-SSSS & & & & - & 0,06 & 0,14 & $0,19^{*}$ & $-0,18^{*}$ & $-0,14$ & $-0,20$ & $0,38^{* *}$ & $0,38^{* *}$ \\
\hline 5-CBQ & & & & & - & $0,41^{*}$ & $0,20^{*}$ & 0,04 & 0,08 & 0,10 & 0,01 & 0,13 \\
\hline 6-CBQ-V & & & & & & - & 0,03 & $-0,01$ & 0,07 & 0,04 & 0,03 & $0,20^{* *}$ \\
\hline 7-SF & & & & & & & - & $0,58^{* *}$ & $0,67^{* *}$ & 0,04 & 0,05 & 0,00 \\
\hline $8-I N$ & & & & & & & & - & $0,35^{\star *}$ & $0,27^{* *}$ & 0,04 & 0,10 \\
\hline 9-SA & & & & & & & & & - & $0,88^{* *}$ & 0,16 & 0,16 \\
\hline $10-\mathrm{FS}$ & & & & & & & & & & - & 0,12 & 0,06 \\
\hline 11-IQ-10 & & & & & & & & & & & - & $0,30^{* *}$ \\
\hline 12-IQ-11 & & & & & & & & & & & & - \\
\hline
\end{tabular}

${ }^{*} p<.05 ;{ }^{* *} p<.01 ; A B=$ Aggression Behaviour; OB = Observation behaviour; $V B=$ Victimization behaviour; SF = Satisfaction with friends; IN = Intimacy; FS = Satisfaction with the Family; SA = Social Activity; IQ-10 = "Do you know if any of your friends have ever lived in any of these situations?"; IQ-11 = "Have you ever experienced any of these situations?". 


\section{CONCLUSIONS}

As expected, the dimensions and variables of the Scales and Questionnaires have positive and statistically significant correlations between them. These results were anticipated because the proximity of the constructs is latent. Regarding the "Satisfaction with Social Support" scale, there are relationships between all dimensions except "Satisfaction with the Family" and "Satisfaction with Friends" ( $r=0.04, \mathrm{n}=145)$.

The results show a prevalence of Observation Behaviour in the Victimization Scale and School Aggression and the dimension Satisfaction with Family in Satisfaction Scale Social Support, translating an impoverishment of the dimension Intimacy. The highest mean score in the Scale of Victimization and School Aggression is obtained in the dimension "Observation Behaviours". These results go towards the studies of Saúde [36], which show a higher incidence in students with Observation Behaviour who are exposed daily to bullying situations and do nothing to help the colleagues who are being victimized. Regarding the "Satisfaction with Social Support" scale, we found that the highest average score is obtained in the "Family Satisfaction" dimension followed closely by the "Social Activity" dimension. It should be noted that the correlations obtained between the "Social Support Satisfaction Scale" and the "Victimization Behaviour" are all negative and statistically significant. This may mean that the higher the frequency of victimization behaviours, the lower the victim's social support.

Statistically significant differences in the average scores of the victimization of Cyberbullying depending on the grade were detected. There are also differences in the three dimensions of the Social Support Satisfaction Scale (Intimacy, Social Activities and Family Satisfaction) between male and female. The dimensions/variables of the scales and questionnaires presented positive and statistically significant correlations, except for the dimensions "Satisfaction with the Family" and "Satisfaction with Friends" $(r=0.04, n=145)$.

It was found that $37 \%$ of the sample has experienced Cyberbullying and $59 \%$ have had knowledge of Cyberbullying situations. One of the main conclusions of this study is directly related to the social support of each adolescent. If the adolescent has cohesive social support, the probability of engaging in such behaviours is less. On the other hand, if social support is reduced, then the individual is more likely to pursue deviant paths because he feels less protected and less oriented throughout adolescence.

This study allows us to conclude that Cyberbullying is constituted as a bullying extension in relation to aggression; threat and provocation planned discomfort and is a repeated behaviour made through social networks. In the study we found that if the adolescent has a cohesive social support, the probability of getting involved in behaviours of this type is much lower. On the other hand, if social support or support is reduced, then the individual is more likely to pursue deviant paths because he feels less protected and less oriented throughout this phase of life, in itself so demanding for the young.

\section{REFERENCES}

[1] A., Neto, "Bullying - comportamento agressivo entre estudantes", Jornal de Pediatria, vol. 81, $\mathrm{n}^{\circ}$ 5, pp.164-172, 2005.

[2] V. Jabes, V. and J. Costa, "O Bullying escolar na perspetiva do gênero masculino e feminino", Colloquium Humanarum, vol. 10, $\mathrm{n}^{\circ}$ 2, pp. 63-78, 2013.

[3] G. M. Batsche and H. M. Knoff, "Bullies and their victims: Understanding a pervasive problem in the schools", School psychology review, vol. 23, pp. 165-165, 1994.

[4] D. Vale and M. Costa, "A violência nas escolas", Lisboa: Instituto de Inovação Educacional, 1998.

[5] C. M. W. Totura, A. E. Green, M. S. Karver and E. L. Gesten, "Multiple informants in the assessment of psychological, behavioral, and academic correlates of bullying and victimization in middle school", Journal of Adolescence, vol. 32, n² 2, pp. 193-211, 2009.

[6] S. Maidel, "Cyberbullying: Um novo risco advindo das tecnologias digitais", Revista Electrónica de Investigación y Docencia, nº 2, pp. 55-60, 2009. 
[7] S. P. Limber, "Addressing youth bullying behaviors", Proceedings from the American Medical Association Educational Forum on Adolescent Health: Youth Bullying. Chicago, IL: American Medical Association, 2002.

[8] D. Olweus, "Victimization by peers: Antecedents and long-term outcomes", Social withdrawal, inhibition, and shyness in childhood, n 315, p. 341, 1993.

[9] T. R. Nansel, M. Overpeck, R. S. Pilla, W. J. Ruan, B. Simons-Morton and P. Scheidt, "Bullying behaviors among US youth: Prevalence and association with psychosocial adjustment", Jama, vol. 285, n 16, pp. 2094-2100, 2001.

[10] L. M. Crothers and E. M. Levinson, "Assessment of bullying: A review of methods and instruments", Journal of Counseling \& Development, vol.82, n 4, pp. 496-503, 2004.

[11] D. Olweus, "Aggression and peer acceptance in adolescent boys: Two short-term longitudinal studies of ratings", Child development, pp. 1301-1313, 1977.

[12] A. Calbo, F. B. Busnello, M. M. Rigoli and C. H. Kristensen, "Bullying na escola: comportamento agressivo, vitimização e conduta pró-social entre pares", Contextos Clínicos, vol. 2 , n 2, pp. 73-80, 2009.

[13] D. Olweus, "A useful evaluation design, and effects of the Olweus Bullying Prevention Program", Psychology, Crime \& Law, vol. 11 n 4, pp. 389-402, 2005.

[14] M. J. D. Martins, "O problema da violência escolar: Uma clarificação e diferenciação de vários conceitos relacionados", Revista Portuguesa de Educação, vol. 18, n 1, pp. 93-105, 2005.

[15] D. Pontzer, "A theoretical test of bullying behavior: Parenting, personality, and the bully/victim relationship", Journal of Family Violence, vol. 25, n 3, pp. 259-273, 2010.

[16] J. I. Cho, J.M. Hendrickson and D. R. Mock, "Bullying status and behavior patterns of preadolescents and adolescents with behavioral disorders", Education and Treatment of Children, vol. 32, n 4, 655-671, 2009.

[17] C. Fante and J. A. Pedra, "Bullying escolar: perguntas e respostas", Artmed, 2008.

[18] H. Campos, H. and S. Jorge, S., "Violência na escola: uma reflexão sobre o Bullying e a prática educativa", Brasília, vol. 23, nº 83, pp. 107-128, 2010.

[19] M. Trevisol and L. Uberti, "Compreender o Bullying por meio do olhar do adolescente testemunha", XI Congresso Nacional de Educação - Seminário Internacional de Representações Sociais, Subjetividade e Educação e Seminário Internacional sobre profissionalização Docente, da Universidade Católica do Paraná, 2013.

[20] K. S. Berger, "Update on bullying at school: Science forgotten?", Developmental review, vol. 27, no 1, pp. 90-126, 2007.

[21] J. Amado, A. Matos, T. Pessoa and T. Jager, "Cyberbullying: um desafio à investigação e à formação", Revista Interações, n 13, 301-326, 2009.

[22] T. Aricak, S. Siyahhan, A. Uzunhasanoglu, S. Saribeyoglu, S. Ciplak, N. Yilmaz, and C. Memmedov, "Cyberbullying among Turkish adolescents." Cyberpsychology \& behavior, vol. 11, n 3, pp. 253-261, 2008.

[23] K. Brown, M, Jackson and W. Cassidy, "Cyber-Bullying: Developing Policy to Direct Responses that are Equitable and Effective in Addressing This Special Form of Bullying", Canadian Journal of Educational Administration and Policy, vol. 57, pp. 1-36, 2006.

[24] G. Wendt and C. Lisboa, "Agressão entre pares no espaço virtual: definições, impactos e desafios do cyberbullying", Psicologia Clínica, Rio de Janeiro, vol. 25, no 1, 73-87, 2013.

[25] L. Pinheiro, "Cyberbullying em Portugal: uma perspetiva sociológica", Master Thesis in Sociology, University of Minho, 2009.

[26] M. S. D. Lima, "Epidemiologia e impacto social", Revista Brasileira de psiquiatria, $n^{\circ}$ 21, pp. $01-$ 05, 1999.

[27] I. G. Sarason, B. R. Sarason, E. N. Shearin and G. R. Pierce, G. R., "A brief measure of social support: Practical and theoretical implications", Journal of social and personal relationships, vol. 4, n 4, pp. 497-510, 1987. 
[28] N. Bolger and D. Amarel, "Effects of social support visibility on adjustment to stress: experimental evidence", Journal of personality and social psychology, vol. 92, n 3, p. 458, 2007

[29] C. H. Tardy, "Social support measurement", American Journal of Community Psychology, vol. 13, $n^{\circ} 2$, pp. 187-202, 1985.

[30] J. L. Ribeiro, "Escala de Satisfação com o Suporte Social (ESSS)", Análise Psicológica, vol. 27, n 3, pp. 547-558, 1999.

[31] J. S. Pendley, L. J. Kasmen, D. L. Miller, J. Donze, C. Swenson and G. Reeves, "Peer and family support in children and adolescents with type 1 diabetes", Journal of pediatric psychology, vol. 27, n 5, pp. 429-438, 2002

[32] A. J. Fuligni, J. S. Eccles, B. L. Barber and P. Clements, "Early adolescent peer orientation and adjustment during high school", Developmental psychology, vol. 37, n 1, p. 28, 2001.

[33] A. Nunes, "Bullying: a influência do suporte sócio-familiar no desenvolvimento de comportamentos agressivos em adolescentes", Master Thesis in Clinical Psychology. Instituto Universitário Ciências Psicológicas, Sociais e da Vida, 2013.

[34] E. Rabaglietti and S. Ciairano, "Quality of friendship relationships and developmental tasks in adolescence", Cognition, Brain, Behavior, vol. 12, n² 2, pp. 183-203, 2008.

[35] S. M. Cunha, "Escala de Vitimação e Agressão Escolar", Lisboa: Faculdade de Psicologia, Universidade Lusófona de Humanidades e Tecnologias, n.d.

[36] A. Saúde, "Bullying e bem-estar psicológico em alunos do $2^{\circ}$ e $3^{\circ}$ ciclo do ensino básico e secundário", Master Thesis in Psychology of Education, Universidade Lusófona de Humanidades e Tecnologias, 2011.

[37] E. Calvete, I. Orue, A. Estévez, L. Villardón and P. Padilla, "Cyberbullying in adolescents: Modalities and aggressors' profile", Computers in Human Behavior, vol. 26, n 5, pp. 11281135, 2010.

[38] T. Pinto "Cyberbullying: Estudo da prevalência de comportamentos de cyberbullying e sua relação com vivências de vergonha e estados emocionais negativos", Master thesis in Clinical Psychology, Instituto Superior Miguel Torga, 2011.

[39] P. Lopes, B. Reis, C. Quintas and I. Amaral, "Direitos digitais: Uma password para o futuro Relatório do inquérito UAL/DECO 2014-2015", Universidade Autónoma de Lisboa, 2015. 